\title{
Biodiversity for multifunctional grasslands: equal productivity in high-diversity low-input and low-diversity high-input systems
}

\author{
A. Weigelt ${ }^{1}$, W. W. Weisser ${ }^{1}$, N. Buchmann ${ }^{2}$, and M. Scherer-Lorenzen ${ }^{2}$ \\ ${ }^{1}$ Institute of Ecology, University of Jena, Dornburger Strasse 159, 07743 Jena, Germany \\ ${ }^{2}$ Institute of Plant Sciences, ETH Zurich, Universitaetsstrasse 2, 8092 Zurich, Switzerland
}

Received: 25 February 2009 - Published in Biogeosciences Discuss.: 24 March 2009

Revised: 17 July 2009 - Accepted: 28 July 2009 - Published: 21 August 2009

\begin{abstract}
Modern grassland management seeks to provide many ecosystem services and experimental studies in resource-poor grasslands have shown a positive relationship between plant species richness and a variety of ecosystem functions. Thus, increasing species richness might help to enhance multifunctionality in managed grasslands if the relationship between species richness and ecosystem functioning is equally valid in high-input grassland systems.

We tested the relative effects of low-input to high-input management intensities and low to high plant species richness. Using a combination of mowing frequencies (1, 2 or 4 cuts per season) and fertilisation levels $(0,100$ and $200 \mathrm{~kg} \mathrm{~N} \mathrm{ha}^{-1} \mathrm{a}^{-1}$ ), we studied the productivity of 78 experimental grassland communities of increasing plant species richness $(1,2,4,8$ or 16 species with 1 to 4 functional groups) in two successive years.
\end{abstract}

Our results showed that in both years higher diversity was more effective in increasing productivity than higher management intensity: the 16-species mixtures had a surplus of $449 \mathrm{~g} \mathrm{~m}^{-2} \mathrm{y}^{-1}$ in 2006 and $492 \mathrm{~g} \mathrm{~m}^{-2} \mathrm{y}^{-1}$ in 2007 over the monoculture yields whereas the high-input management resulted in only $315 \mathrm{~g} \mathrm{~m}^{-2} \mathrm{y}^{-1}$ higher productivity in 2006 and $440 \mathrm{~g} \mathrm{~m}^{-2} \mathrm{y}^{-1}$ in 2007 than the low-input management. In addition, high-diversity low-input grassland communities had similar productivity as low-diversity high-input communities. The slopes of the biodiversity - productivity relationships significantly increased with increasing levels of management intensity in both years.

We conclude that the biological mechanisms leading to enhanced biomass production in diverse grassland communities are as effective for productivity as a combination of several agricultural measures. Our results demonstrate that high-diversity low-input grassland communities provide not

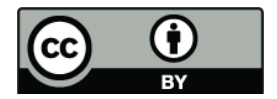

Correspondence to: A. Weigelt (alexandra.weigelt@uni-jena.de) only a high diversity of plants and other organisms, but also ensure high forage yields, thus granting the basis for multifunctional managed grasslands.

\section{Introduction}

Current and future management goals recognise the benefits of multifunctionality in grassland agriculture providing a large number of ecosystem services (Sanderson et al., 2007; Lemaire et al., 2005). These services include ecosystem processes with direct functional benefits in an agricultural context such as yield, decomposition, nutrient leaching, pollination, soil conservation and resistance to weed invasion along with forage stability under changing climatic conditions. Other goals comprise ecologically important services such as enhanced carbon sequestration and the mitigation of greenhouse gas emissions as well as non-market benefits such as land conservation, the maintenance of landscape structure or even aesthetic values (Sanderson et al., 2004).

In grasslands - as in any ecosystem - most of these services depend on the activity of biological organisms and processes. In the last two decades, ecologists comprehensively studied the effect of biodiversity on the provision of such ecosystem services (Kinzig et al., 2002; Loreau et al., 2002; Hooper et al., 2005) and it appears that many ecological processes are more effective with increasing species diversity (Balvanera et al., 2006; Cardinale et al., 2006; Diaz et al., 2006; Hector and Bagchi, 2007). Most of these studies concentrated on relatively species rich and nutrient-poor grasslands and found that higher diversity leads to increased productivity (here defined as aboveground biomass production; e.g. Tilman et al., 1997a; Hector et al., 1999; Roscher et al., 2005; Cardinale et al., 2007), higher associated diversity of insects (Siemann et al., 1998) or soil organisms (Milcu et al., 2008), more effective soil nitrogen use (Tilman et al., 1996, 1997a; Scherer-Lorenzen et al., 2003; Oelmann et al.,

Published by Copernicus Publications on behalf of the European Geosciences Union. 
2007), higher stability of forage yield or vegetation composition (Tilman et al., 2006; Weigelt et al., 2008) and lower invasibility by weeds (Symstad, 2000; Roscher et al., 2009a, b). Recently, high-diversity low-input grasslands have even been advocated for biofuel production due to their beneficial $\mathrm{CO}_{2}$ balance (Tilman, 2006, 2007; Fargione et al., 2008a, b; Hill et al., 2009).

If these results were also valid under nutrient-rich conditions, management for increased species diversity would be an ecological approach to enhancing the multifunctionality of grasslands (Sanderson et al., 2004; Hector and Loreau, 2005; Hooper et al., 2005) and could even provide additional benefits for biodiversity conservation (Robertson and Swinton, 2005; Tscharntke et al., 2005). Strong evidence for this approach comes from the European-wide COST experiment which recently showed that even a moderate increase of plant species richness from 1 to 4 species had strong positive effects in intensively managed grasslands (Kirwan et al., 2007). Thus, comparing the effects of biodiversity under resource-poor and resource-rich conditions may be the key to the debate about the relevance and interpretation of biodiversity studies. Across-system comparisons usually support the view that changes in resource availability are more important for productivity than changes in diversity (Hooper et al., 2005). Only a few experiments in grasslands have so far independently manipulated plant diversity and resource availability, and indeed much larger effects on grassland productivity were reported of resources than of diversity (He et al., 2002; Fridley, 2002, 2003; Dimitrakopoulos and Schmid, 2004; Spehn et al., 2005). In contrast, Rixen et al. (2007) found comparable effects of nitrogen addition and increasing plant diversity, while Reich et al. (2001) reported stronger effects of plant diversity than light fertilisation on productivity. Interestingly, however, the slope of the diversity-productivity relationship was steeper under high resource availability than under low resource availability in most of these cases.

Agricultural experience shows, however, that lowdiversity grasslands can be highly productive due to agricultural intensification using fertilisation, irrigation and highyielding cultivars. Nonetheless, grassland productivity has been successfully increased by sowing specifically designed mixtures, combining $\mathrm{N}_{2}$-fixing legume species with fastgrowing grass species (Hopkins, 2000; Barnes et al., 2007). These low-diversity high-input grasslands simultaneously show high forage yields and low plant species richness due to the competitive dominance of fast growing species (Di Tommaso and Aarssen, 1989). However, high-diversity grasslands mainly persist on extensively managed sites which are often nutrient poor, too dry or are otherwise disadvantageous for intensive management practises. These high-diversity low-input grasslands usually have low yields (Tallowin and Jefferson, 1999).

Sanderson et al. (2004) reviewed agricultural studies combining biodiversity with fertilisation and/or grazing in pastures and found equivocal results where much of the positive effects of biodiversity were attributed to the sampling effect (inclusion of a highly productive species). The only ecological experiment including fertilisation on intensively managed grasslands was again part of the COST experiment and showed a positive effect of species mixtures even under very high levels of nitrogen addition (450 $\mathrm{kg} \mathrm{Nha}^{-1} \mathrm{y}^{-1}$, Lüscher et al., 2008).

We studied the effects of biodiversity and management intensity on productivity and are, to our knowledge, the first to combine a large grassland biodiversity gradient with a gradient of management intensity simulating common agricultural practice in Central Europe. The goal of this study is not to test specific plant compositions (e.g. abundant mixtures in semi-natural grasslands), but to quantify the relative effects of species richness and management intensity on the productivity of a large variety of grassland communities growing under equal abiotic conditions. It is only in the light of this fundamental mechanisms that a translation of our results to field sites is possible. We manipulated species richness $(1,2,4,8,16$ species) as well as functional group richness $(1,2,3$, 4 functional groups) in 78 large experimental plots $(20 \times 20 \mathrm{~m})$. On these plots we established a management intensity gradient ranging from low-input (single mowing, no fertilisation) to high-input (four times mowing, $200 \mathrm{~kg} \mathrm{Nha}^{-1} \mathrm{y}^{-1}$ fertilisation) hay meadows for two successive years. We were asking the following questions: (1) Does increasing plant diversity or increasing management intensity have a larger effect on aboveground productivity? (2) Is the slope of the biodiversity-productivity relationship affected by management intensity? (3) What are the implications of our findings for multifunctional grassland management?

\section{Materials and methods}

\subsection{Study site and experimental design}

This study was carried out on the plots of a biodiversityecosystem functioning experiment in Jena (Thuringia, Germany, $50^{\circ} 55^{\prime} \mathrm{N}, 11^{\circ} 35^{\prime} \mathrm{E} ; 130 \mathrm{~m}$ a.s.l., Roscher et al., 2004). The area around Jena has a mean annual air temperature of $9.3^{\circ} \mathrm{C}$ and mean annual precipitation of $587 \mathrm{~mm}$. The "Jena Experiment" was established in May 2002 in the floodplain of the river Saale on a former arable field. Since soil texture varies across the site, the field was divided into four blocks to account for the effects of soil heterogeneity.

The experimental communities were seeded in a randomized block design in 78 large plots of $20 \times 20 \mathrm{~m}$ with a gradient of species richness $(1,2,4,8$ and 16) and functional group richness (1, 2, 3 or 4 functional groups) per plot. The species were taken from a pool of 60 species typical to Central European Molinio-Arrhenatheretea meadows. The 60 plant species were categorised into four functional groups: grasses (16 species), small herbs (12 species), 
tall herbs ( 20 species), and legumes (12 species) using cluster analysis based on an ecological and morphological trait matrix (Roscher et al., 2004). Mixtures were created using constrained random selection of species from the 60 species pool. In total, 16 replicates for 1, 2, 4 and 8 species mixtures and 14 replicates for the 16 species mixtures were established by sowing 1000 viable seeds per $\mathrm{m}^{2}$, equally divided by the number of species present. Species richness, functional group richness and presence of functional group were varied as orthogonally as possible such that e.g. in the 16 replicates of 4 species mixtures there were each 4 plots containing either $1,2,3$ or 4 functional groups. In addition, all 60 species were sown on 4 plots which were used for comparison in this study (see below). Plots were regularly weeded to maintain the sown species richness levels, and did not receive any fertiliser during the first three years after establishment.

In Central Europe, grassland management covers a gradient of intensities, depending on production goals, vegetation composition and site conditions. Meadows with high biodiversity and conservation value usually do not receive fertiliser or manure and are mown only once or twice. In contrast, highly productive leys for intensive forage production receive large amounts of fertilisers or liquid manure and are mown several times per year (Tallowin and Jefferson, 1999). In Thuringia, where the "Jena Experiment" is located, there are four common agricultural practices for grasslands on floodplains comparable to our experimental site: (1) permanent grasslands in agri-environmental schemes without fertilisation and a late first cut (July) with 1-2 cuts per year, (2) extensively managed permanent grassland without fertilisation and 2-3 cuts per year, (3) conventionally managed permanent grassland with fertilisation (up to $200 \mathrm{~kg} \mathrm{~N} \mathrm{ha}^{-1} \mathrm{a}^{-1}$, applied as mineral NPK fertiliser or manure) and 3-4 cuts per year, and (4) leys, i.e., clover-grass or clover-alfalfa-grass mixtures with reduced $\mathrm{N}$ fertilisation and 3-4 cuts per year. These latter mixtures are typically tilled and resown every $2-3$ years. To mimic a management intensity gradient, we established four subplots of $1.6 \times 4 \mathrm{~m}$ in each of the large $20 \times 20 \mathrm{~m}$ plots, combining mowing frequency and fertilisation intensity as listed in Table 1. Thus, our management intensity gradient includes both, extremes of low-input extensive management (M1 F0: one cut per year, no fertilisation) and of high-input intensive management (M4 F200: four cuts, high fertilisation) and two intermediate levels. The core area of the large plots served as one treatment level, with mowing twice a year and no fertiliser (M2 F0). A full factorial design with all fertilisation levels per mowing treatment was not realised due to logistical constraints but also such a design would include factor combinations that are not reasonable for agricultural practice, e.g., frequent mowing without fertilisation. As a consequence, we are not able to separate the effects of mowing and fertilisation but analyse a gradient of increasing management intensity instead. Our results therefore strictly apply to the range and type of our man-
Table 1. The management intensity gradient. Treatments are established on subplots within larger experimental plots except the M2 F0 which represents the management intensity of the whole experimental field. Mowing frequency $(\mathrm{M})$ is given in cuts per year, all fertilisation values $(\mathrm{F})$ are given in $\mathrm{kg} \mathrm{ha}^{-1} \mathrm{a}^{-1}$. Nitrogen is applied as $\mathrm{NO}_{3}-\mathrm{N}$ and $\mathrm{NH}_{4}-\mathrm{N}$ in equal proportions, phosphorus as $\mathrm{P}_{2} \mathrm{O}_{5}-\mathrm{P}$ and potassium as $\mathrm{K}_{2} \mathrm{O}-\mathrm{K}$. The last column gives the gradient of increasing management intensity used for linear fit in model 1 (see Table 3).

\begin{tabular}{|c|c|c|c|c|c|}
\hline \multirow{2}{*}{$\begin{array}{l}\text { Management } \\
\text { Treatments }\end{array}$} & \multirow{2}{*}{$\begin{array}{r}\text { Mowing } \\
\text { Frequency }\end{array}$} & \multicolumn{3}{|c|}{ Fertilisation } & \multirow{2}{*}{$\begin{array}{r}\text { Linear } \\
\text { Gradient }\end{array}$} \\
\hline & & $\mathrm{N}$ & $\mathrm{P}$ & K & \\
\hline M1 F0 & 1 & 0 & 0 & 0 & 1 \\
\hline M2 F0 & 2 & 0 & 0 & 0 & 2 \\
\hline M2 F100 & 2 & 100 & 43.6 & 83 & 3 \\
\hline M4 F100 & 4 & 100 & 43.6 & 83 & 4 \\
\hline M4 F200 & 4 & 200 & 87.2 & 166 & 5 \\
\hline
\end{tabular}

agement gradient in combination with the diversity gradient realised. The management experiment consisted of a total of 390 subplots $(78 \times 4$ management subplots plus $78 \times$ core area). To characterise the management intensities, we will use the abbreviations given in the first column of Table 1 throughout the text. The assignment of treatments to subplots was randomised except for the M1 F0 subplots which were always placed at the plot margins due to logistical constraints. In April 2005, all four subplots assigned to the management experiment (all except M2 F0 in Table 1) were fertilised once with $50 \mathrm{~kg} \mathrm{Nha}^{-1} \mathrm{a}^{-1}, 31 \mathrm{~kg} \mathrm{P}_{2} \mathrm{O}_{5} \mathrm{ha}^{-1} \mathrm{a}^{-1}$, $31 \mathrm{~kg} \mathrm{~K}_{2} \mathrm{Oha}^{-1} \mathrm{a}^{-1}$, and $2.75 \mathrm{~kg} \mathrm{MgO} \mathrm{ha}^{-1} \mathrm{a}^{-1}$. From control measurements in the field, we believe the effect of this single fertilisation event on productivity in the following years was negligible and, if anything, reduced the difference between diversity and management effects, but it might have initiated first changes in species composition. Starting in 2006, subplots received fertiliser divided into two equal portions (equal to 50 and $100 \mathrm{~kg} \mathrm{~N} \mathrm{ha}^{-1} \mathrm{a}^{-1}$ per application in the F100 and F200 treatments, respectively) in early spring (6 April 2006 and 15 March 2007) and after the first mowing (26 June 2006 and 27 June 2007). Fertiliser was applied as commercial NPK-pellets using a lawn fertiliser distributor. Plots were cut either once, twice or four times during the growing season with sickle bar mowers at approximately $3 \mathrm{~cm}$ a.g.l. The first cut was on 2 May 2006 and 2007 (M4 F100 and M4 F200), the second cut was 16-23 June 2006 and 6-15 June 2007 (whole field except M1 F0 subplots), the third cut was on 27 July 2006 and 24 July 2007 (M4 F100 and M4 F200), while the last cut was 614 September 2006 and 5-14 September 2007 (whole field). All cut material was removed from the plots using a belt rake and additional hand raking. Mowing, fertilising and weeding were done block by block such that any effect of maintenance differences between blocks was corrected for by the block effect in the statistical analysis. 


\subsection{Data collection}

Aboveground plant biomass was harvested shortly before mowing of each subplot, cutting one randomly selected $0.2 \times 0.5 \mathrm{~m}$ area at $3 \mathrm{~cm}$ a.g.l. In the core area of the large plots (M2 F0), four random samples of $0.2 \times 0.5 \mathrm{~m}$ were harvested and sorted to sown species, weeds and dead biomass. Only one of these four samples was randomly selected and is used in our analysis. Harvested biomass of sown species was dried $\left(70^{\circ} \mathrm{C}, 48 \mathrm{~h}\right)$ and weighed. To ease the comparison between ecological datasets commonly measuring biomass or hay yield (dried at $70^{\circ} \mathrm{C}$ ) and data derived from agriculturally managed sites using dry matter (dried at $105^{\circ} \mathrm{C}$ ), we additionally measured the dry mass of subsamples of sown species biomass and found a mean water content of $6.94 \pm 0.99 \%$ in our biomass samples. The mean dry matter given for managed grasslands in Thuringia (from the Thuringia Agricultural Institute, TLL, 2007) was multiplied with a factor of 1.07 to correct for this difference.

\subsection{Data analysis}

Annual aboveground biomass production (here used as a proxy for net primary productivity) was calculated as sum of all single biomass harvests per treatment, plot and year. Productivity in 2006 and 2007 was analysed for all 390 subplots. We used one fitting sequence of split-plot analysis of variance to test the combined effects of diversity, management and year with untransformed biomass values (Table 2). All models used the exact sequence of parameters given in Table 2 except for the numbered terms which were additionally fitted as contrasts in three separate models. In model 1 , the effects of species richness, functional group richness and management intensity were decomposed into linear contrasts (see Table 1 for linear gradient of management intensity) and deviations between linear and categorical effects (Table 3). Moreover, the effect of management intensity was decomposed into categorical contrasts of mowing and fertilisation to explain the underlying effects of mowing frequency and fertiliser application. In model 2 (Table 4), mowing was fitted first, while in model 3 (Table 5), fertilisation was fitted first.

\section{Results}

In plots with higher species richness aboveground productivity significantly increased in 2006 (2007) from $299 \pm 95 \mathrm{~g} \mathrm{~m}^{-2} \mathrm{y}^{-1}\left(304 \pm 83 \mathrm{~g} \mathrm{~m}^{-2} \mathrm{y}^{-1}\right)$ in low-diversity grasslands to $694 \pm 124 \mathrm{~g} \mathrm{~m}^{-2} \mathrm{y}^{-1}\left(758 \pm 75 \mathrm{~g} \mathrm{~m}^{-2} \mathrm{y}^{-1}\right)$ in high-diversity grasslands with 16 species and even increased to $1026 \pm 27 \mathrm{~g} \mathrm{~m}^{-2} \mathrm{y}^{-1}\left(1334 \pm 84 \mathrm{~g} \mathrm{~m}^{-2} \mathrm{y}^{-1}\right)$ in highdiversity grasslands with 60 species when plots were mown twice and not fertilised (M2 F0, Fig. 1, Nr. 1 in Table 2). Plots with a higher number of functional groups also had significantly greater aboveground productivity (Fig. 1, Nr. 2 in Table 2). There was a linear effect of species richness on productivity while the categorical effect was significant for the number of functional groups (Nr. 1a, b and 2a, b in Table 3). Communities with three functional groups often resulted in higher productivity than those containing all four functional groups (Fig. 1). Productivity varied between both years and was significantly higher in 2007 compared to 2006 (Table 2: Year). However, regression slopes did not differ significantly between both years (Fig. 1, Table 2: no significant $\log (\mathrm{SR}) \times$ Year or $\mathrm{FG} \times$ Year interactions).

Management intensity had a significant and positive effect on productivity which was largely explained by a linear effect of management intensity (Nr. 3 in Table 2 and Nr. $3 a$, b in Table 3). Both, mowing frequency and fertiliser application had significant positive effects on productivity, independent of the fitting sequence in the model, e.g. the mean differences in fertiliser application between M2 F0 vs. M2 F100 and between M4 F100 vs. M4 F200 were significant (Nr. 3a, $\mathrm{b}$ in Table 4) as well as the mean differences in mowing frequency between M1 F0 vs. M2 F0 and between M2 F100 vs. M4 F100 (Nr. 3a, b in Table 5). However, the effect of mowing frequency on productivity was stronger than the fertiliser effect as mowing frequency explained a much larger part of the overall variation in management intensity compared to fertilisation (compare Nr. 3a in Tables 4 and 5).

The interaction between the effects of management intensity and species richness was only marginally significant, but the interaction with a linear management gradient was significant (Nr. 4a in Table 3). Hence, the slope of the biodiversityproductivity relationship increased linearly with increasing management intensity. In Fig. 1, this effect is best visible for the regression slopes of the management gradient extremes in 2006 (M1 F0: $\mathrm{y}=146+76.4 \times, R^{2}=0.88$ and M4 F200: $\mathrm{y}=284+133.4 \times, R^{2}=0.98$ ) and 2007 (M1 F0: $\mathrm{y}=75+88.9 \times$, $R^{2}=0.98$ and M4 F200: $\mathrm{y}=385+148.1 \times, R^{2}=0.94$ ). Again, a larger part of the overall interaction was explained by changes in mowing frequencies and not fertilisation. The changing slope of the biodiversity-productivity relationship with increasing management intensity did not differ between years and was thus stable over time (Table 2: no significant $\log (\mathrm{SR}) \times$ Management $\times$ Year interaction) .

The presence of legumes significantly increased aboveground productivity. This effect weakened over time (Table 2: significant Legumes $\times$ Year interaction), and the difference in productivity between plots with and without legumes was smaller in 2007 than in 2006 (Fig. 2). However, the slope of the biodiversity-productivity relationship was steeper in plots containing legumes (Table 2: significant $\log (\mathrm{SR}) \times$ Legumes interaction), and this effect remained equally strong in the second year. The effect of management intensity also differed in plots with and without legumes (Nr. 5 in Table 2). Within any level of mowing frequency, fertilisation significantly increased productivity on plots without legumes, but had only a minor effect on plots with legumes (Fig. 2, M2 F0 vs. M2 F100 and M4 F100 vs. 
Table 2. Split-plot analysis of variance of aboveground biomass production per year. The table gives the order in which terms were entered into the model. Numbered terms (first column) were additionally fit as contrasts in three separate models. These models are given in Tables 3-5. P-values in bold represent significant factors in the models.

\begin{tabular}{|c|c|c|c|c|c|c|}
\hline $\mathrm{Nr}$. & Source & Df & SS & MS & $\mathrm{F}$ & $\mathrm{P}$ \\
\hline \multicolumn{7}{|c|}{ Within plots } \\
\hline & Block & 3 & 1458460 & 486153 & 2.37 & 0.079 \\
\hline 1 & Species richness (SR) & 4 & 20484297 & 5121074 & 24.96 & $<0.001$ \\
\hline \multirow[t]{8}{*}{2} & Functional groups (FG) & 3 & 2102654 & 700885 & 3.42 & $\mathbf{0 . 0 2 3}$ \\
\hline & Legumes & 1 & 1973831 & 1973831 & 9.62 & 0.003 \\
\hline & Grasses & 1 & 605883 & 605883 & 2.95 & 0.091 \\
\hline & Tall herbs & 1 & 190498 & 190498 & 0.93 & 0.339 \\
\hline & $\log (\mathrm{SR}) \times$ legumes & 1 & 1321428 & 1321428 & 6.44 & 0.014 \\
\hline & $\log (\mathrm{SR}) \times$ grasses & 1 & 341231 & 341231 & 1.66 & 0.202 \\
\hline & $\log (S R) \times$ tall herbs & 1 & 72270 & 72270 & 0.35 & 0.555 \\
\hline & Plot residuals & 61 & 12514717 & 205159 & & \\
\hline \multicolumn{7}{|c|}{ Within subplots } \\
\hline 3 & Management & 4 & 13422300 & 3355575 & 45.38 & $<0.001$ \\
\hline \multirow[t]{2}{*}{4} & $\log (\mathrm{SR}) \times$ Management & 4 & 591745 & 147936 & 2.00 & 0.095 \\
\hline & FG $\times$ Management & 4 & 187754 & 46939 & 0.63 & 0.638 \\
\hline \multirow[t]{4}{*}{5} & Legumes $\times$ Management & 4 & 3849601 & 962400 & 13.01 & $<0.001$ \\
\hline & Grasses $\times$ Management & 4 & 328029 & 82007 & 1.11 & 0.352 \\
\hline & Tall herbs $\times$ Management & 4 & 445789 & 111447 & 1.51 & 0.200 \\
\hline & Subplot residuals & 288 & 21297635 & 73950 & & \\
\hline \multicolumn{7}{|c|}{ Within Years } \\
\hline & Year & 1 & 535148 & 535148 & 13.60 & $<0.001$ \\
\hline & $\log (\mathrm{SR}) \times$ Year & 1 & 58821 & 58821 & 1.49 & 0.222 \\
\hline & $\mathrm{FG} \times$ Year & 1 & 178 & 178 & 0.00 & 0.946 \\
\hline & Legumes $\times$ Year & 1 & 1109293 & 1109293 & 28.18 & $<0.001$ \\
\hline & Grasses $\times$ Year & 1 & 22398 & 22398 & 0.57 & 0.451 \\
\hline & Tall herbs $\times$ Year & 1 & 10168 & 10168 & 0.26 & 0.612 \\
\hline \multirow[t]{7}{*}{6} & Management $\times$ Year & 4 & 731667 & 182917 & 4.65 & 0.001 \\
\hline & $\log (\mathrm{SR}) \times$ Management $\times$ Year & 4 & 10990 & 2747 & 0.07 & 0.991 \\
\hline & $\mathrm{FG} \times$ Management $\times$ Year & 4 & 452093 & 11023 & 2.87 & 0.023 \\
\hline & Legumes $\times$ Management $\times$ Year & 4 & 103268 & 25817 & 0.66 & 0.623 \\
\hline & Grasses $\times$ Management $\times$ Year & 4 & 228392 & 57098 & 1.45 & 0.217 \\
\hline & Tall herbs $\times$ Management $\times$ Year & 4 & 82312 & 20578 & 0.52 & 0.719 \\
\hline & Residuals & 360 & 14170460 & 39362 & & \\
\hline
\end{tabular}

M4 F200). Increasing mowing frequency from one to two had a positive effect on the productivity of all plots (Fig. 2, M1 F0 vs. M2 F0). Increasing mowing frequency from two to four on fertilised plots, however, had a minor negative effect on productivity on plots without legumes, but a significant negative effect on plots with legumes (Fig. 2, M2 F100 vs. M4 F100). The presence of grasses and tall herbs showed no significant direct effects and no interaction with species richness (Table 2: Grasses or Tall herbs), while presence of small herbs revealed the same result if they were included into the model instead of tall herbs (data not shown).

Overall, mean aboveground productivity per $\mathrm{m}^{2}$ increased by $112 \mathrm{~g} \mathrm{~m}^{-2} \mathrm{y}^{-1}$ in 2006 and $123 \mathrm{~g} \mathrm{~m}^{-2} \mathrm{y}^{-1}$ in 2007 whenever the number of species doubled, such that increasing diversity from monocultures to 16 species mixtures resulted in a mean increase of $449 \mathrm{~g} \mathrm{~m}^{-2} \mathrm{y}^{-1}$ in 2006 and $492 \mathrm{~g} \mathrm{~m}^{-2} \mathrm{y}^{-1}$ in 2007 . Increasing functional diversity from 1 to 4 functional groups resulted in a mean increase of only $262 \mathrm{~g} \mathrm{~m}^{-2} \mathrm{y}^{-1}$ in 2007 and $286 \mathrm{~g} \mathrm{~m}^{-2} \mathrm{y}^{-1}$ in 2007 . Increasing management intensity from low-input (2006: M1 F0; 296 $\pm 28 \mathrm{~g} \mathrm{~m}^{-2} \mathrm{y}^{-1}, 2007: 248 \pm 30 \mathrm{~g} \mathrm{~m}^{-2} \mathrm{y}^{-1}$ ) to high-input intensity (2006: M4 F200; 544 $\pm 31 \mathrm{~g} \mathrm{~m}^{-2} \mathrm{y}^{-1}$, 2007: $674 \pm 40 \mathrm{~g} \mathrm{~m}^{-2} \mathrm{y}^{-1}$ ) resulted in a mean productivity increase of approximately $250 \mathrm{~g} \mathrm{~m}^{-2} \mathrm{y}^{-1}$ in 2006 and $425 \mathrm{~g} \mathrm{~m}^{-2} \mathrm{y}^{-1}$ in 2007 . However, highest productivity was reached in the intermediate management level M2 F100 (2006: $611 \pm 44 \mathrm{~g} \mathrm{~m}^{-2} \mathrm{y}^{-1}, 2007: 688 \pm 46 \mathrm{~g} \mathrm{~m}^{-2} \mathrm{y}^{-1}$ ), resulting in a maximum management effect of $315 \mathrm{~g} \mathrm{~m}^{-2} \mathrm{y}^{-1}$ and $440 \mathrm{~g} \mathrm{~m}^{-2} \mathrm{y}^{-1}$ in 2006 and 2007, respectively. The effect of fertilisation was evident in a direct comparison of plots 
Table 3. Split-plot analysis of variance of aboveground biomass production per year using the same fitting sequence as in Table 2 except for the terms numbered in the first column. These 6 terms were decomposed into linear contrasts and deviations between linear and categorical effects. The linear management gradient was defined as given in Table 1. Some terms were subsumed to minimise overlap between Table 2 and 3. P-values in bold represent significant factors in the models.

\begin{tabular}{|c|c|c|c|c|c|c|}
\hline Nr. & Source & Df & SS & MS & $\mathrm{F}$ & $\mathrm{P}$ \\
\hline \multicolumn{7}{|c|}{ Within plots } \\
\hline & Block & 3 & 1458460 & 486153 & 2.37 & 0.079 \\
\hline $1 \mathrm{a}$ & Linear log species richness (SR) & 1 & 20406872 & 20406872 & 99.47 & $<0.001$ \\
\hline $1 \mathrm{~b}$ & $\mathrm{SR}$ residuals & 3 & 77425 & 25808 & 0.13 & 0.944 \\
\hline $2 \mathrm{a}$ & Linear functional groups (FG) & 1 & 661582 & 661582 & 3.22 & 0.077 \\
\hline \multirow[t]{3}{*}{$2 b$} & FG residuals & 2 & 1441072 & 720536 & 3.51 & 0.036 \\
\hline & $\mathrm{FG}$ presence and $\mathrm{FG} \times \mathrm{SR}$ & 6 & 4505141 & 750857 & 3.66 & 0.004 \\
\hline & Plot residuals & 61 & 12514717 & 205159 & & \\
\hline \multicolumn{7}{|c|}{ Within subplots } \\
\hline $3 a$ & Linear Management & 1 & 6848647 & 6848647 & 92.61 & $<0.001$ \\
\hline $3 b$ & Management residuals & 3 & 6573654 & 2191218 & 29.63 & $<0.001$ \\
\hline $4 \mathrm{a}$ & $\log (\mathrm{SR}) \times$ linear Management & 1 & 446963 & 446963 & 6.04 & 0.015 \\
\hline \multirow[t]{2}{*}{$4 \mathrm{~b}$} & $\log (S R) \times$ Management residuals & 3 & 144783 & 48261 & 0.65 & 0.582 \\
\hline & FG $\times$ Management & 4 & 187754 & 46939 & 0.63 & 0.638 \\
\hline $5 \mathrm{a}$ & Legumes $\times$ linear Management & 1 & 1153224 & 1153224 & 15.59 & $<0.001$ \\
\hline \multirow[t]{3}{*}{$5 b$} & Legumes $\times$ Management residuals & 3 & 2696377 & 898792 & 12.15 & $<\mathbf{0 . 0 0 1}$ \\
\hline & Management $\times$ residual presence FG & 8 & 773818 & 96727 & 1.31 & 0.239 \\
\hline & Subplot residuals & 288 & 21297635 & 73950 & & \\
\hline \multicolumn{7}{|c|}{ Within Years } \\
\hline & Year $\times \mathrm{SR} \times \mathrm{FG} \times$ presence $\mathrm{FG}$ & 6 & 1736006 & 289334 & 7.35 & $<0.001$ \\
\hline $6 \mathrm{a}$ & Linear Management $\times$ Year & 1 & 329069 & 329069 & 8.36 & 0.004 \\
\hline \multirow[t]{4}{*}{$6 \mathrm{~b}$} & Management residuals $\times$ Year & 3 & 402598 & 134199 & 3.41 & 0.018 \\
\hline & $\log (\mathrm{SR}) \times$ Management $\times$ Year & 4 & 10990 & 2747 & 0.07 & 0.991 \\
\hline & FG and presence $F G \times$ Management $\times$ Year & 16 & 866065 & 54129 & 1.38 & 0.151 \\
\hline & Residuals & 360 & 14170460 & 39362 & & \\
\hline
\end{tabular}

with equal mowing frequency and resulted in a mean productivity increase of $144 \mathrm{~g} \mathrm{~m}^{-2} \mathrm{y}^{-1}$ and $139 \mathrm{~g} \mathrm{~m}^{-2} \mathrm{y}^{-1}$ between M2 F0 and M2 F100 plots and an increase of $56 \mathrm{~g} \mathrm{~m}^{-2} \mathrm{y}^{-1}$ and $168 \mathrm{~g} \mathrm{~m}^{-2} \mathrm{y}^{-1}$ between M4 F100 and M4 F200 plots in 2006 and 2007, respectively. Evidently, increasing species richness had a stronger effect on productivity than management intensification. Increasing functional group richness had a lower effect on aboveground productivity than management intensification, but a higher effect than fertilisation alone.

\section{Discussion}

\subsection{The effect of mowing and fertilisation on productivity}

Our results support the well established agricultural knowledge that fertilisation increases yields, while intermediate mowing frequency results in highest grassland productivity (Hopkins, 2000; Barnes et al., 2007). In our experiment, plots with mowing frequency of one (M1 F0) had the low- est productivity and those with mowing frequency of two and moderate fertiliser (M2 F100) showed highest productivity, while plots with mowing frequency of four (M4 F100, M4 F200) only reached intermediate productivity levels despite higher fertiliser input. This is due to the fact that most grasses cease to produce new leaves after flowering while they quickly regrow after being cut (Voigtländer and Jakob, 1987). Frequent mowing (four times in our case), however, implies a rather early defoliation during the period of fastest plant growth in spring, which cannot be compensated by subsequent regeneration and regrowth, especially not in legumes and tall herbs.

The management intensity-productivity relationship strongly depended on the functional composition of the community, with the presence of legumes being particularly important. The positive effect of legume presence on productivity is significantly reduced under high mowing frequency and fertilisation (Fig. 2). The overriding importance of $\mathrm{N}_{2}$-fixing legumes in grassland communities is well known in both ecology (Tilman et al., 2001; Spehn et al., 2002) and agriculture where grass-clover mixtures are commonly used 
Table 4. Split-plot analysis of variance of aboveground biomass production per year using the same fitting sequence as in Table 2 except for the terms numbered in the first column. These 4 terms were decomposed into categorical contrasts of mowing and fertilisation to explain the underlying effects of mowing frequency and fertiliser application. Mowing was fitted first in this table and fertilisation in Table 5. Some terms were subsumed to minimise overlap between Tables 2 and 4. P-values in bold represent significant factors in the models.

\begin{tabular}{|c|c|c|c|c|c|c|}
\hline Nr. & Source & Df & SS & MS & $\mathrm{F}$ & $\mathrm{P}$ \\
\hline \multicolumn{7}{|c|}{ Within plots } \\
\hline & Block & 3 & 1458460 & 486153 & 2.37 & 0.079 \\
\hline & Species richness (SR) & 4 & 20484297 & 5121074 & 24.96 & $<\mathbf{0 . 0 0 1}$ \\
\hline & Functional groups (FG) & 3 & 2102654 & 700885 & 3.42 & 0.023 \\
\hline & $\mathrm{FG}$ presence and $\mathrm{FG} \times \mathrm{SR}$ & 6 & 4505141 & 750857 & 3.66 & 0.004 \\
\hline & Plot residuals & 61 & 12514717 & 205159 & & \\
\hline \multicolumn{7}{|c|}{ Within subplots } \\
\hline $3 a$ & Mowing & 2 & 10878073 & 5439036 & 73.55 & $<\mathbf{0 . 0 0 1}$ \\
\hline $3 b$ & Fertilisation & 2 & 2544227 & 1272114 & 17.20 & $<\mathbf{0 . 0 0 1}$ \\
\hline $4 a$ & $\log (\mathrm{SR}) \times$ Mowing & 2 & 451766 & 225883 & 3.05 & 0.049 \\
\hline \multirow[t]{2}{*}{$4 b$} & $\log (\mathrm{SR}) \times$ Fertilisation & 2 & 139979 & 69990 & 0.95 & 0.389 \\
\hline & FG $\times$ Management & 4 & 187754 & 46939 & 0.63 & 0.638 \\
\hline $5 \mathrm{a}$ & Legumes $\times$ Mowing & 2 & 2938971 & 1469485 & 19.87 & $<\mathbf{0 . 0 0 1}$ \\
\hline \multirow[t]{3}{*}{$5 b$} & Legumes $\times$ Fertilisation & 2 & 910630 & 455315 & 6.16 & 0.002 \\
\hline & Management $\times$ residual presence $\mathrm{FG}$ & 8 & 773818 & 96727 & 1.31 & 0.239 \\
\hline & Subplot residuals & 288 & 21297635 & 73950 & & \\
\hline \multicolumn{7}{|c|}{ Within Years } \\
\hline & Year $\times \mathrm{SR} \times \mathrm{FG} \times$ presence $\mathrm{FG}$ & 6 & 1736006 & 289334.3 & 7.35 & $<\mathbf{0 . 0 0 1}$ \\
\hline $6 a$ & Mowing $\times$ Year & 2 & 488482 & 244241 & 6.20 & 0.002 \\
\hline \multirow[t]{4}{*}{$6 b$} & Fertilisation $\times$ Year & 2 & 243185 & 121593 & 3.09 & 0.047 \\
\hline & $\log (\mathrm{SR}) \times$ Management $\times$ Year & 4 & 10990 & 2747 & 0.07 & 0.991 \\
\hline & FG and presence $F G \times$ Management $\times$ Year & 16 & 866065 & 54129 & 1.38 & 0.151 \\
\hline & Residuals & 360 & 14170460 & 39362 & & \\
\hline
\end{tabular}

as highly managed and most productive grassland systems (Hopkins, 2000; Barnes et al., 2003). Facilitative interactions among $\mathrm{N}_{2}$-fixing legumes and non-fixers usually decrease with soil fertility as $\mathrm{N}_{2}$-fixation can be reduced under high fertilisation levels and because co-occurring nonfixing species are less dependent on the additional $\mathrm{N}$-input by legumes (Hartwig, 1998; Nyfeler et al., 2006, 2008).

\subsection{The relative importance of biodiversity and management intensity on productivity}

Our experiment tested the effects of management intensity and biodiversity on aboveground productivity of grassland communities. Our main result is that the increasing plant species richness levels were more effective than the imposed levels of increasing management intensity. Functional group richness also significantly increased productivity but its effect was about equal to the effect of management intensification applied in 2006 and lower than the management effect in 2007.

Biodiversity experiments have repeatedly demonstrated that productivity is positively affected by species richness (Tilman et al., 1997a; Hector et al., 1999; Roscher et al.,
2005) which is assumed to be driven by the complementarity (including facilitation) and the selection effect (also referred to as sampling or dominance, Aarssen, 1997; Huston, 1997; Tilman et al., 1997b; Loreau, 1998). In the Jena Experiment both mechanisms play a role, but the strength and relative importance of multi-species complementarity increased over time while species-specific selection effects strongly weakened (Marquard et al., 2009).

Overall, increasing biodiversity from 1 to 16 species led to a mean increase in productivity of $449 \mathrm{~g} \mathrm{~m}^{-2} \mathrm{y}^{-1}$ $\left(492 \mathrm{~g} \mathrm{~m}^{-2} \mathrm{y}^{-1}\right)$, while management intensification (i.e., mowing frequency and fertiliser application) resulted in $248 \mathrm{~g} \mathrm{~m}^{-2} \mathrm{y}^{-1}\left(426 \mathrm{~g} \mathrm{~m}^{-2} \mathrm{y}^{-1}\right)$ in the first (second) year of the study. Fertilisation from 0 to $100 \mathrm{~kg} \mathrm{Nha}^{-1} \mathrm{y}^{-1}$ alone resulted in $144 \mathrm{~g} \mathrm{~m}^{-2} \mathrm{y}^{-1}$ increase in productivity in 2006 (139 $\mathrm{g} \mathrm{m}^{-2} \mathrm{y}^{-1}$ in 2007). Unfertilised 60-species mixtures yielded as much as $1026 \pm 27 \mathrm{~g} \mathrm{~m}^{-2} \mathrm{y}^{-1}$ in 2006 and $1334 \pm 84 \mathrm{~g} \mathrm{~m}^{-2} \mathrm{y}^{-1}$ in 2007 (Fig. 1, M2 F0). These productivity changes quantify the relative effects of changes in species richness levels and imposed changes in management intensity in a variety of grassland communities growing under equal abiotic conditions. It is thus only within these boundaries that a translation to managed grassland sites is 
Table 5. Split-plot analysis of variance of aboveground biomass production per year using the same fitting sequence as in Table 2 except for the terms numbered in the first column. These 4 terms were decomposed into categorical contrasts of mowing and fertilisation to explain the underlying effects of mowing frequency and fertiliser application. Fertilisation was fitted first in this table and mowing in Table 4. Some terms were subsumed to minimise overlap between Tables 2 and 5. P-values in bold represent significant factors in the models.

\begin{tabular}{|c|c|c|c|c|c|c|}
\hline Nr. & Source & Df & SS & MS & $\mathrm{F}$ & $\mathrm{P}$ \\
\hline \multicolumn{7}{|c|}{ Within plots } \\
\hline & Block & 3 & 1458460 & 486153 & 2.37 & 0.079 \\
\hline & Species richness (SR) & 4 & 20484297 & 5121074 & 24.96 & $<0.001$ \\
\hline & Functional groups $(\mathrm{FG})$ & 3 & 2102654 & 700885 & 3.42 & 0.023 \\
\hline & $\mathrm{FG}$ presence and $\mathrm{FG} \times \mathrm{SR}$ & 6 & 4505141 & 750857 & 3.66 & 0.004 \\
\hline & Plot residuals & 61 & 12514717 & 205159 & & \\
\hline \multicolumn{7}{|c|}{ Within subplots } \\
\hline $3 a$ & Fertilisation & 2 & 7257902 & 3628951 & 49.07 & $<0.001$ \\
\hline $3 b$ & Mowing & 2 & 6164398 & 3082199 & 41.68 & $<0.001$ \\
\hline $4 a$ & $\log (\mathrm{SR}) \times$ Fertilisation & 2 & 437974 & 218987 & 2.96 & 0.053 \\
\hline \multirow[t]{2}{*}{$4 \mathrm{~b}$} & $\log (\mathrm{SR}) \times$ Mowing & 2 & 153772 & 76886 & 1.04 & 0.355 \\
\hline & $\mathrm{FG} \times$ Management & 4 & 187754 & 46939 & 0.63 & 0.638 \\
\hline $5 \mathrm{a}$ & Legumes $\times$ Fertilisation & 2 & 1813349 & 906675 & 12.26 & $<\mathbf{0 . 0 0 1}$ \\
\hline \multirow[t]{3}{*}{$5 b$} & Legumes $\times$ Mowing & 2 & 2036251 & 1018126 & 13.77 & $<0.001$ \\
\hline & Management $\times$ residual presence $F G$ & 8 & 773818 & 96727 & 1.31 & 0.239 \\
\hline & Subplot residuals & 288 & 21297635 & 73950 & & \\
\hline \multicolumn{7}{|c|}{ Within Years } \\
\hline & Year $\times \mathrm{SR} \times \mathrm{FG} \times$ presence $\mathrm{FG}$ & 6 & 1736006 & 289334 & 7.35 & $<0.001$ \\
\hline $6 \mathrm{a}$ & Fertilisation $\times$ Year & 2 & 329724 & 164862 & 4.19 & 0.016 \\
\hline \multirow[t]{4}{*}{$6 \mathrm{~b}$} & Mowing $\times$ Year & 2 & 401942 & 200971 & 5.11 & 0.007 \\
\hline & $\log (\mathrm{SR}) \times$ Management $\times$ Year & 4 & 10990 & 2747 & 0.07 & 0.991 \\
\hline & $\mathrm{FG}$ and presence $\mathrm{FG} \times$ Management $\times$ Year & 16 & 866065 & 54129 & 1.38 & 0.151 \\
\hline & Residuals & 360 & 14170460 & 39362 & & \\
\hline
\end{tabular}

possible. High diversity plots cannot be sustained in fertilised meadows (Plantureux et al., 2005) due to competitive displacement of subordinate species under nutrient input (Di Tommaso and Aarssen, 1989; Gough et al., 2000). For this reason, long-term experiments with highly diverse but fertilised plots are not possible. Interestingly, species loss on fertilised plots in our experiment was slow enough to ensure a distinct diversity gradient ranging from monocultures to a mean of $11.5 \pm 0.28$ realised species over all management intensities in the sown 16 species mixtures in 2007 compared to $12.4 \pm 0.50$ in 2005 before the start of the fertilisation. Experience in the Jena Experiment also shows that highly diverse mixtures can be easily maintained without fertilisation due to the high resistance against invasion by non-seeded species (Mwangi et al., 2007; Roscher et al., 2009b).

On the other side of the diversity gradient, species poor grasslands which are agriculturally optimized for the single function of hay production (e.g., clover-grass mixtures using particular varieties) with fertiliser input (ca. $200 \mathrm{~kg} \mathrm{Nha}^{-1} \mathrm{y}^{-1}$ and other nutrients) and up to 6 cuts per year can achieve forage yields between 1000 and $1400 \mathrm{~g} \mathrm{~m}^{-2} \mathrm{y}^{-1}$ (Tallowin and Jefferson, 1999). For Thuringia, where the study site is located, mean forage yields are $790 \mathrm{~g} \mathrm{~m}^{-2} \mathrm{y}^{-1}$ for conventionally managed permanent grassland with fertilisation and 3-4 cuts per year, and $1030 \mathrm{~g} \mathrm{~m}^{-2} \mathrm{y}^{-1}$ for clover-grass mixtures without fertilisation ("R" in Fig. 1, Thuringia Agricultural Institute (TLL), public communication, 2007, corrected for difference between dry matter and yield; see methods). Thus, even agriculturally improved grasslands with reduced multifunctionality do not result in higher hay/forage yields compared to our highly diverse and multifunctional mixtures which produced $1026 \mathrm{~g} \mathrm{~m}^{-2} \mathrm{y}^{-1}$.

Overall, we conclude that the biological mechanisms leading to enhanced productivity in mixtures can be as effective for yield production as a combination of several agricultural measures, including selection of highly productive cultivars and high input of energy and fertiliser.

\subsection{The interactive effects of biodiversity and management intensity on productivity}

Our results show that the positive biodiversity-productivity relationship is found in grasslands strongly differing in management intensities. So far, the only other large scale ecological study linking species richness to productivity in 


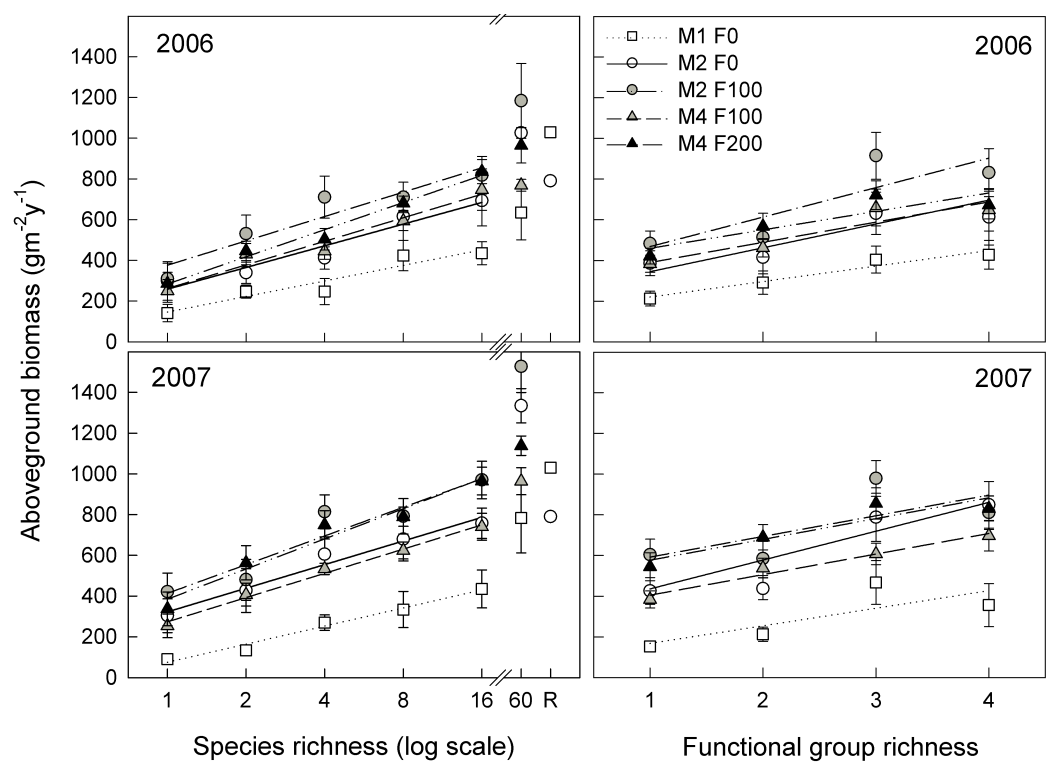

Fig. 1. Aboveground biomass in 2006 (upper panels) and 2007 (lower panels). Means $( \pm \mathrm{SE})$ for species richness and functional group richness are given for all five treatments (abbreviations as given in Table 1). The 60 species mixtures (60) and the reference plots (R) were not included in the linear regressions which were all significant $(p<0.05)$. The reference plots represent aboveground biomass in 2006 for conventional permanent grassland (white circle) and grass-clover mixtures (white square) for comparable sites in Thuringia.

managed ecosystems used intensively managed grasslands on all of the 28 different sites in Europe, but without any management intensity gradient within sites, except one (Kirwan et al., 2007; Lüscher et al., 2008). The species richness treatment in this experiment consisted of monocultures and four-species mixtures (with different abundances of each of the four component species). Here, the fertilised and the unfertilised plots showed transgressive overyielding, indicating a significant positive effect on productivity of mixing four species relative to species in monoculture (Kirwan et al., 2007; Lüscher et al., 2008). With increasing fertilisation applied at one site, the positive effect of mixtures decreased but was still significant (Lüscher et al., 2008). In this experiment, however, no changes along a larger diversity gradient or possible interactions with other management practises such as mowing were tested.

Studies combining a gradient of biodiversity with manipulations of $\mathrm{N}$-supply found an increasingly positive effect of higher resource supply with increasing species richness, i.e., the slope of the biodiversity-productivity relationship became steeper at higher levels of fertilisation. These results were observed in both short term pot or small raised-bed plot experiments (He et al., 2002; Fridley, 2002, 2003), and in field studies on larger plots mimicking atmospheric $\mathrm{N}$ deposition (Reich et al., 2001, 2004). Only one field study simulating ion input through snow additives in subalpine grasslands found no change in the slope of the biodiversityproductivity relationship (Rixen et al., 2007). Our study is the first large-scale field experiment to show a significant interaction (Nr. 4a in Table 3) and thus an increasing slope of

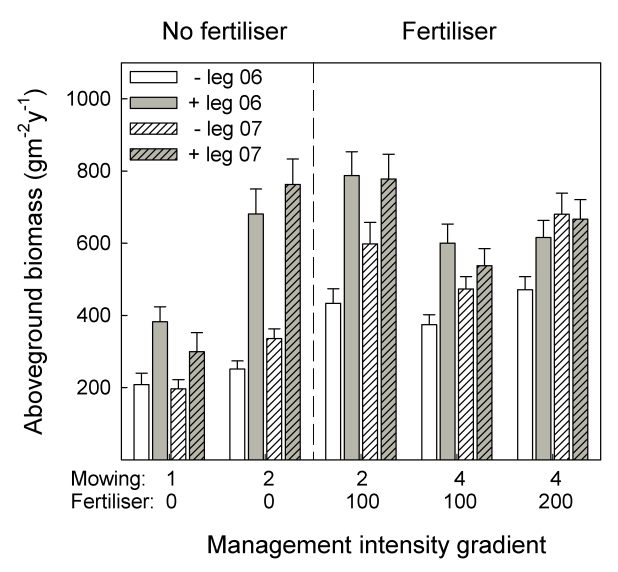

Fig. 2. Aboveground biomass of plots without legumes (white bars) and with legumes (grey bars) in 2006 (open bars) and 2007 (hatched bars). Means over all plots are given for the management intensity gradient. The dashed line separates the non-fertilised (left) from the fertilised (right) plots.

the biodiversity-productivity relationship for a management intensity gradient ranging from extensive, low-input grasslands to intensive, high-input grasslands. It has been argued that increased soil resource partitioning and facilitation (Reich et al., 2001, 2004; He et al., 2002; Dimitrakopoulos and Schmid, 2004) were the driving mechanisms for the increase in slope at higher nutrient levels or, alternatively, enhanced aboveground growth form differences among species leading to increased light partitioning (Fridley, 2002, 2003; Gross et al., 2007). At limited resource availability, increases in the 
slope of the diversity-productivity relationship were also attributed to increased heterogeneity of resources (Tylianakis et al., 2008). In the "Jena Experiment", resource partitioning especially between legumes and other functional groups is an important driver of increased productivity with increasing species richness due to the fertilisation effect of $\mathrm{N}$-fixing legumes (Marquard et al., 2009). Thus, the potential of complementarity for soil resources in fertilised subplots might be more pronounced in species-rich compared to species-poor communities, leading to changes in the slope of the diversityproductivity relationship, although we cannot rule out other mechanisms. In fact, results from a recent grassland biodiversity experiment do not support the view that complementarity for soil nitrogen is a major driver of positive diversityproductivity relationships (von Felten et al., 2009), so there is still room to advance our understanding of underlying mechanisms of diversity effects on ecosystem functioning.

\subsection{Implications for multifunctional grassland management}

Multifunctional grassland management seeks to provide a large number of ecosystem services (Sanderson et al., 2007; Lemaire et al., 2005), including ecological processes that have been shown to be more effective with increasing species diversity (Balvanera et al., 2006; Cardinale et al., 2006; Diaz et al., 2006; Hector and Bagchi, 2007). At present, multifunctionality is primarily achieved at the landscape or farm level, with high-intensity plots managed for productivity, and low-intensity plots managed for conservation of biodiversity and ecosystem services on more marginal sites. Agri-environmental incentives have been established to promote this management changes in favour of biodiversity, with varying success (Kleijn and Sutherland, 2003). Our results show that management for multifunctionality might work even at the plot scale when grasslands on fertile soils are managed less intensively and biodiversity effects are used for increased productivity. Thus increasing biodiversity in managed grasslands might actually help to meet the goals of multifunctionality and provide additional benefits in terms of nature conservation (Robertson and Swinton, 2005; Tscharntke et al., 2005). Besides the provision of forage, conservation functions and a wide variety of other ecosystem services, the possible economic value of biodiversity might be an additional incentive to include high-diversity low-input communities in farming systems (Balmford et al., 2002; Hodgson et al., 2005). As demonstrated by Bullock and colleagues (Bullock et al., 2007), enhancement of hay-yield by recreation of diverse grasslands may recoup costs of species-rich seed mixtures after few years, and may increase farm income in the long term. Our study shows that high-diversity lowinput grasslands with high productivity could complement such farming systems, integrating both productivity and advantages of biodiversity for other ecosystem services even on the field scale. For permanent grasslands, which cover one third of the utilised agricultural area in Europe (Smit et al., 2008), highly diverse communities composed of complementary species and $\mathrm{N}_{2}$-fixing legumes could provide an excellent agro-economic and ecological option for sustainable and highly productive grassland use.

Acknowledgements. The Jena Experiment is funded by the Deutsche Forschungsgemeinschaft (DFG, FOR 456), with additional support from the Friedrich Schiller University of Jena, the Max Planck Society, the University of Zurich, and the Swiss National Science Foundation (grant 3100AO-107531 to B. Schmid). The management experiment has received financial support by ETH Zurich (funds from N. Buchmann). We thank B. Schmid for his support throughout the experiment and during manuscript preparation. We are grateful to the many people involved in the management of the experiment, especially the gardeners and technical staff.

Edited by: J. Middelburg

\section{References}

Aarssen, L. W.: High productivity in grassland ecosystems: effected by species diversity or productive species?, Oikos, 80(1), 183184, 1997.

Balmford, A., Bruner, A., Cooper, P., Costanza, R., Farber, S., Green, R. E., Jenkins, M., Jefferiss, P., Jessamy, V., Madden, J., Munro, K., Myers, N., Naeem, S., Paavola, J., Rayment, M., Rosendo, S., Roughgarden, J., Trumper, K., and Turner, R. K.: Ecology - Economic reasons for conserving wild nature, Science, 297, 950-953, 2002.

Balvanera, P., Pfisterer, A. B., Buchmann, N., He, J.-S., Nakashizuka, T., Raffaelli, D., and Schmid, B.: Quantifying the evidence for biodiversity effects on ecosystem functioning and services, Ecol. Lett., 9, 1146-1156, 2006.

Barnes, R. F., Nelson, C. F., Collins, M., and Moore, K. J.: Forages. An introduction to grassland agriculture, Iowa State Press, Ames, 6th edn., 2003.

Barnes, R. F., Nelson, C. F., Moore, K. J., and Collins, M.: Forages. To the science of grassland agriculture, Blackwell Publishing, Ames, Oxford, Victoria, 6th edn., 2007.

Bullock, J. M., Pywell, R. F., and Walker, K. J.: Long-term enhancement of agricultural production by restoration of biodiversity, J. Appl. Ecol., 44, 6-12, 2007.

Cardinale, B. J., Srivastava, D. S., Duffy, J. E., Wright, J. P., Downing, A. L., Sankaran, M., and Jouseau, C.: Effects of biodiversity on the functioning of trophic groups and ecosystems, Nature, 443, 989-992, 2006.

Cardinale, B. J., Wrigh, J. P., Cadotte, M. W., Carroll, I. T., Hector, A., Srivastava, D. S., Loreau, M., and Weis, J. J.: Impacts of plant diversity on biomass production increase through time because of species complementarity, P. Natl. Acad. Sci. USA, 104, 1812318128, 2007.

Di Tommaso, A. and Aarssen, L. W.: Resource manipulations in natural vegetation: a review, Vegetatio, 84, 9-29, 1989.

Diaz, S., Fargione, J., Chapin III, F. S., and Tilman, D.: Biodiversity loss threatens human well-being, Plos Biol., 4, 1300-1305, 2006.

Dimitrakopoulos, P. G. and Schmid, B.: Biodiversity effects increase linearly with biotope space, Ecol. Lett., 7, 574-583, 2004. 
Fargione, J., Hill, J., Tilman, D., Polasky, S., and Hawthorne, P.: Biofuels: Effects on land and fire - Response, Science, 321, 199200, 2008a.

Fargione, J., Hill, J., Tilman, D., Polasky, S., and Hawthorne, P.: Land clearing and the biofuel carbon debt, Science, 319, 12351238, 2008b.

Fridley, J. D.: Resource availability dominates and alters the relationship between species diversity and ecosystem productivity in experimental plant communities, Oecologia, 132, 271-277, 2002.

Fridley, J. D.: Diversity effects on production in different light and fertility environments: an experiment with communities of annual plants, J. Ecol., 91, 396-406, 2003.

Gough, L., Osenberg, G. W., Gross, K. L., and Collins, S. L.: Fertilization effects on species density and primary productivity in herbaceous plant communities, Oikos, 89, 428-439, 2000.

Gross, N., Suding, K. N., Lavorel, S., and Roumet, C.: Complementarity as a mechanism of coexistence between functional groups of grasses, J. Ecol., 95, 1296-1305, 2007.

Hartwig, U. A.: The regulation of symbiotic $\mathrm{N}_{2}$ fixation: a conceptual model of $\mathrm{N}$ feedback from the ecosystem to the gene expression level, Perspect. Plant Ecol., 1, 92-120, 1998.

He, J.-S., Bazzaz, F. A., and Schmid, B.: Interactive effects of diversity, nutrients and elevated $\mathrm{CO}_{2}$ on experimental plant communities, Oikos, 97, 337-348, 2002.

Hector, A., Schmid, B., Beierkuhnlein, C., Caldeira, M. C., Diemer, M., Dimitrakopoulos, P. G., Finn, J. A., Freitas, H., Giller, P. S., Good, J., Harris, R., Hogberg, P., Huss-Danell, K., Joshi, J., Jumpponen, A., Korner, C., Leadley, P. W., Loreau, M., Minns, A., Mulder, C. P. H., O’Donovan, G., Otway, S. J., Pereira, J. S., Prinz, A., Read, D. J., Scherer-Lorenzen, M., Schulze, E. D., Siamantziouras, A. S. D., Spehn, E. M., Terry, A. C., Troumbis, A. Y., Woodward, F. I., Yachi, S., and Lawton, J. H.: Plant diversity and productivity experiments in European grasslands, Science, 286, 1123-1127, 1999.

Hector, A. and Loreau, M.: Relationships between biodiverstiy and production in grasslands at local and regional scales, in: Grassland: a global resource, edited by: McGilloway, D. A., Wageningen Academic Publishers, Wageningen, 295-304, 2005.

Hector, A. and Bagchi, R.: Biodiversity and ecosystem multifunctionality, Nature, 448, 188-191, 2007.

Hill, J., Polasky, S., Nelson, E., Tilman, D., Huo, H., Ludwig, L., Neumann, J., Zheng, H. C., and Bonta, D.: Climate change and health costs of air emissions from biofuels and gasoline, P. Natl. Acad. Sci. USA, 106, 2077-2082, 2009.

Hodgson, J. G., Montserrat-Marti, G., Tallowin, J., Thompson, K., Diaz, S., Cabido, M., Grime, J. P., Wilson, P. J., Band, S. R., Bogard, A., Cabido, R., Caceres, D., Castro-Diez, P., Ferrer, C., Maestro-Martinez, M., Perez-Rontome, M. C., Charles, M., Cornelissen, J. H. C., Dabbert, S., Perez-Harguindeguy, N., Krimly, T., Sijtsma, F. J., Strijker, D., Vendramini, F., Guerrero-Campo, J., Hynd, A., Jones, G., Romo-Diez, A., Espuny, L. D., VillarSalvador, P., and Zak, M. R.: How much will it cost to save grassland diversity?, Biol. Conserv., 122, 263-273, 2005.

Hooper, D. U., Chapin, F. S. I., Ewel, J. J., Hector, A., Inchausti, P., Lavorel, S., Lawton, J. H., Lodge, D. M., Loreau, M., Naeem, S., Schmid, B., Setälä, H., Symstad, A. J., Vandermeer, J., and Wardle, D. A.: Effects of biodiversity on ecosystem functioning: a consensus of current knowledge, Ecol. Monogr., 75, 3-35, 2005.
Hopkins, A.: Herbage production, in: Grass: its production and utilization, edited by: Hopkins, A., Blackwell Publishing, Oxford, 99-110, 2000.

Huston, M. A.: Hidden Treatments in ecological experiments: reevaluating the ecosystem function of biodiversity, Oecologia, 110, 449-460, 1997.

Kinzig, A. P., Pacala, S. W., and Tilman, D.: The Functional Consequences of Biodiversity, Princeton University Press, Princeton, 2002.

Kirwan, L., Lüscher, A., Sebastia, M. T., Finn, J. A., Collins, R. P., Porqueddu, C., Helgadottir, S., Baadshaug, O. H., Brophy, C., Coran, C., Dalmannsdottir, S., Delgado, I., Elgersma, A., Fothegill, P., Frankow-Lindberg, B. E., Golinski, P., Grieu, P., Gustavsson, A. M., Höglind, M., Hueguenin-Elie, O., Iliadis, C., Jorgensen, M., Kadziuliene, Z., Karyotis, T., Lunnan, Malengier, M., Maltoni, S., Meyer, V., Nyfeler, D., Nykanen-Kurki, P., Parente, J., Smit, H. J., Thumm, U., and Connolly, J.: Evenness drives consistent diversity effects in intensive grassland systems across 28 European sites, J. Ecol., 95, 530-539, 2007.

Kleijn, D. and Sutherland, W. J.: How effective are European agrienvironment schemes in conserving and promoting biodiversity?, J. Appl. Ecol., 40, 947-969, 2003.

Lemaire, G., Wilkins, R., and Hodgson, J.: Challenges for grassland science: managing research priorities, Agr. Ecosyst. Environ., 108, 99-108, 2005.

Loreau, M.: Biodiversity and ecosystem functioning: A mechanistic model, P. Natl. Acad. Sci. USA, 95, 5632-5636, 1998.

Loreau, M., Naeem, S., and Inchausti, P.: Biodiversity and Ecosystem Functioning - Synthesis and Perspectives, Oxford University Press, Oxford, 2002.

Lüscher, A., Finn, J. A., Connolly, J., Sebastia, M. T., Collins, R., Fothergill, M., Porqueddu, C., Brophy, C., Huguenin-Elie, M., Kirwan, L., Nyfeler, D., and Helgadottir, A.: Benefits of sward diversity for agricultural grasslands, Biodiversity, 9, 2932, 2008.

Marquard, E., Weigelt, A., Temperton, V. M., Roscher, C., Schumacher, J., Buchmann, N., Fischer, M., Weisser, W. W., and Schmid, B.: Plant species richness and functional composition drive overyielding in a 6-year grassland experiment, J. Ecol., 97, 696-704, 2009.

Milcu, A., Partsch, S., Scherber, C. D., Weisser, W. W., and Scheu, S.: Earthworms and legumes control litter decomposition in a plant diversity gradient, Ecology, 89, 1872-1882, 2008.

Mwangi, P. N., Schmitz, M., Scherber, C., Roscher, C., Schumacher, J., Scherer-Lorenzen, M., Weisser, W. W., and Schmid, B.: Niche pre-emption increases with species richness in experimental plant communities, J. Ecol., 95, 65-78, 2007.

Nyfeler, D., Huguenin-Elie, M., Frossard, E., and Lüscher, A.: Regulation of symbiotic nitrogen fixation in grass-clover mixtures, Grassland Sci. Eur., 11, 246-248, 2006.

Nyfeler, D., Huguenin-Elie, M., Suter, M., Frossard, E., and Lüscher, A.: Well-balanced grass-legume mixtures with low nitrogen fertilization can be as productive as highly fertilized grass monocultures, Grassland Sci. Eur., 13, 197-199, 2008.

Oelmann, Y., Wilcke, W., Temperton, V. M., Buchmann, N., Roscher, C., Schumacher, J., Schulze, E. D., and Weisser, W. W.: Soil and plant nitrogen pools as related to plant diversity in an experimental grassland, Soil Sci. Soc. Am. J., 71, 720-729, 2007. 
Plantureux, S., Peeters, A., and McCracken, D.: Biodiversity in intensive grasslands: Effect of management, improvement and challenges, Agronomy Research, 3, 153-164, 2005.

Reich, P. B., Knops, J., Tilman, D., Craine, J., Ellsworth, D., Tjoelker, M., Lee, T., Wedin, D., Naeem, S., Bahauddin, D., Hendrey, G., Jose, S., Wrage, K., Goth, J., and Bengston, W.: Plant diversity enhances ecosystem responses to elevated $\mathrm{CO}_{2}$ and nitrogen deposition, Nature, 410, 809-812, 2001.

Reich, P. B., Tilman, D., Naeem, S., Ellsworth, D. S., Knops, J., Craine, J., Wedin, D., and Trost, J.: Species and functional group diversity independently influence biomass accumulation and its response to $\mathrm{CO}_{2}$ and N, P. Natl. Acad. Sci. USA, 101, 1010110106, 2004.

Rixen, C., Huovinen, C., Huovinen, K., Stöckli, V., and Schmid, B.: A plant diversity $\times$ water chemistry experiment in subalpine grassland, Perspect, Plant Ecol., 10, 51-61, 2007.

Robertson, G. P. and Swinton, S. M.: Reconciling agricultural productivity and environmental integrity: a grand challenge for agriculture, Front. Ecol. Environ., 3, 38-46, 2005.

Roscher, C., Schumacher, J., Baade, J., Wilcke, W., Gleixner, G., Weisser, W. W., Schmid, B., and Schulze, E. D.: The role of biodiversity for element cycling and trophic interactions: an experimental approach in a grassland community, Basic Appl. Ecol., 5, 107-121, 2004.

Roscher, C., Temperton, V. M., Scherer-Lorenzen, M., Schmitz, M., Schumacher, J., Schmid, B., Buchmann, N., Weisser, W. W., and Schulze, E. D.: Overyielding in experimental grassland communities - irrespective of species pool or spatial scale, Ecol. Lett., 8, 419-429, 2005.

Roscher, C., Temperton, V. M., Buchmann, N., and Schulze, E. D.: Community assembly and biomass production in regularly and never weeded experimental grasslands, Acta Oecol., 35, 206217, 2009a.

Roscher, C., Beßler, H., Oelmann, Y., Engels, C., Wilcke, W., and Schulze, E. D.: Resources, recruitment limitation and invader species identity determine pattern of spontaneous invasion in experimental grasslands, J. Ecol., 97, 32-47, 2009 b.

Sanderson, M. A., Skinner, R. H., Barker, D. J., Edwards, G. R., Tracy, B. F., and Wedin, D. A.: Plant species diversity and management of temperate forage and grazing land ecosystems, Crop Sci., 44, 1132-1144, 2004.

Sanderson, M. A., Goslee, S. C., Soder, K. J., Skinner, R. H., Tracy, B. F., and Deak, A.: Plant species diversity, ecosystem function, and pasture management - A perspective, Can. J. Plant Sci., 87, 479-487, 2007.

Scherer-Lorenzen, M., Palmborg, C., Prinz, A., and Schulze, E. D.: The role of plant diversity and composition for nitrate leaching in grasslands, Ecology, 84, 1539-1552, 2003.

Siemann, E., Tilman, D., Haarstad, J., and Ritchie, M.: Experimental tests of the dependence of arthropod diversity on plant diversity, Am. Nat., 152, 738-750, 1998.

Smit, H. J., Metzger, M. J., and Ewert, F.: Spatial distribution of grassland productivity and land use in Europe, Agr. Syst., 98, 208-219, 2008.

Spehn, E., Scherer-Lorenzen, M., Schmid, B., Hector, A., Caldeira, M. C., Dimitrakopoulos, P. G., Finn, J. A., Jumpponen, A., O’Donovan, G., Pereira, J. S., Schulze, E. D., Troumbis, A. Y., and Körner, C.: The role of legumes as a component of biodiversity in a cross-European study of grassland biomass nitrogen,
Oikos, 98, 205-218, 2002.

Spehn, E., Hector, A., Joshi, J., Scherer-Lorenzen, M., Schmid, B., Bazeley-White, E., Beierkuhnlein, C., Caldeira, M. C., Diemer, M., Dimitrakopoulos, P. G., Finn, J. A., Koricheva, J., Leadley, P., Loreau, M., Minns, A., Mulder, C. P. H., O’Donovan, G., Otway, S., Palmborg, C., Pereira, J. S., Pfisterer, A. B., Prinz, A., Read, D. J., Schulze, E. D., Siamantziouras, A.-S. D., Terry, A. C., Troumbis, A. Y., Woodward, F. I., Yachi, S., and Lawton, J. H.: Ecosystem effects of biodiversity manipulations in European grasslands, Ecol. Monogr., 75, 37-63, 2005.

Symstad, A.: A test of the effects of functional group richness and composition on grassland invasibility, Ecology, 81, 99-109, 2000.

Tallowin, J. R. B. and Jefferson, R. G.: Hay production from lowland semi-natural grasslands: a review of implications for ruminant livestock systems, Grass Forage Sci., 54, 99-115, 1999.

Tilman, D., Wedin, D., and Knops, J.: Productivity and sustainability influenced by biodiversity in grassland ecosystems, Nature, 379, 718-720, 1996.

Tilman, D., Knops, J., Wedin, D., Reich, P., Ritchie, M., and Siemann, E.: The influence of functional diversity and composition on ecosystem processes, Science, 277, 1300-1302, 1997a.

Tilman, D., Lehman, C. L., and Thomson, K. T.: Plant diversity and ecosystem productivity: theoretical considerations, P. Natl. Acad. Sci. USA, 94, 1857-1861, 1997b.

Tilman, D., Reich, P., Knops, J., Wedin, D., Mielke, T., and Lehman, C.: Diversity and Productivity in a Long-Term Grassland Experiment, Science, 294, 843-845, 2001.

Tilman, D.: Carbon-Negative Biofuels from Low-Input HighDiversity Grassland Biomass, Science, 314, 1598-1600, 2006.

Tilman, D., Reich, P. B., and Knops, J. M. H.: Biodiversity and ecosystem stability in a decade-long grassland experiment, Nature, 442, 629-632, 2006.

Tilman, D., Hill, J., and Lehman, C.: Response to comment on "Carbon-negative biofuels from low-input high-diversity grassland biomass", Science, 316(5831), p. 1567, 2007.

Tscharntke, T., Klein, A.-M., Kruess, A., Steffan-Dewenter, I., and Thies, C.: Landscape perspectives on agricultural intensification and biodiversity - ecosystem service management, Ecol. Lett., 8, 857-874, 2005.

Tylianakis, J. M., Rand, T. A., Kahmen, A., Klein, A.-M., Buchmann, N., Perner, J., and Tscharntke, T.: Resource heterogeneity moderates the biodiversity-function relationship in real world ecosystems, Plos Biol., 6, 947-956, 2008.

Voigtländer, G. and Jacob, H.: Gründlandwirtschaft und Futterbau, Ulmer Verlag, 1987.

Von Felten, S., Buchmann, N., Hector, A., Niklaus, P. A., Schmid, B., and Scherer-Lorenzen, M.: Belowground nitrogen partitioning in experimental grassland plant communities of varying species richness, Ecology, 90, 1389-1399, 2009.

Weigelt, A., Schumacher, J., Roscher, C., and Schmid, B.: Does biodiversity increase spatial stability in plant community biomass?, Ecol. Lett., 11, 338-347, 2008. 